\title{
Two rare endocrinological diagnoses in one patient
}

\author{
Ivana Ságová1, Daniela Kantárová ${ }^{2}$ Peter Vaňuga ${ }^{1}$ \\ ${ }^{1}$ Department of Endocrinology, National Institute of Endocrinology and Diabetology, Lubochňa, Slovakia \\ ${ }^{2}$ Department of Internal Medicine I, University Hospital Martin, Slovakia
}

Key words: acromegaly; insulin-like growth factor 1; Klinefelter syndrome; treatment

Acromegaly is a rare disorder with an incidence rate of 3-4 patients per million per year [1]. Klinefelter syndrome (KS) is the most common sex chromosome disorder, occurring in about $1 / 500$ live male births [2]. The coincidence of multiple endocrinopathies is rare but possible. We report the case of a 33-year-old man diagnosed with both of those rare conditions - acromegaly and 47, XXY Klinefelter syndrome.

The patient was admitted to the Endocrinology Department of the National Institute of Endocrinology and Diabetology in Lubochňa with clinical manifestation of acromegaly. He had a tall stature (body height 195 $\mathrm{cm}$, weight $90 \mathrm{~kg}$ ) and enlarged acral parts of the body (including enlargement of hands, feet, facial bones, nose, and tongue with wider spaces between his teeth). He suffered from headache, excessive sweating, and arthralgia. Presence of infertility with reduced facial and pubic hair and small, firm testes could not be explained by the diagnosis of acromegaly. Laboratory tests revealed high level of growth hormone $(\mathrm{GH})$ not suppressed after glucose administration, high level of insulin like growth factor 1 (IGF-1) and IGF binding protein 3 (IGFBP3), and low testosterone concentration with high concentration of luteinizing hormone (LH) and follicle stimulating hormone (FSH) (Tab. 1). Magnetic resonance imaging scan showed a $25 \times 18 \times 18 \mathrm{~mm}$ macroadenoma of the pituitary gland with dominant cystoid component, with dedifferentiation of adenohypophysis and neurohypophysis tissue and deviation of the infundibulum to the left. There was no compression of the optic chiasm (Fig. 1A). Diagnosis of acromegaly was established. Perimetry test, abdominal ultrasound, and echocardiography ruled out visual field defects, hepatomegaly, and cardiomyopathy, respectively. Subsequently, transsphenoidal resection of the pituitary
Table 1. Laboratory tests over time

\begin{tabular}{|c|c|c|c|}
\hline Laboratory tests & $\begin{array}{c}\text { Initial } \\
\text { examination }\end{array}$ & $\begin{array}{l}6 \text { months } \\
\text { after first } \\
\text { operation }\end{array}$ & $\begin{array}{c}\text { After } \\
\text { reoperation }\end{array}$ \\
\hline $\begin{array}{l}\text { Thyroxine [pmol/L] } \\
\mathrm{N}:(10.5-22.7)\end{array}$ & 15.79 & 17.57 & 14.29 \\
\hline $\begin{array}{l}\text { Thyroid stimulating } \\
\text { hormone }[\mathrm{mlU} / \mathrm{L}] \\
\mathrm{N}:(0.35-5.10)\end{array}$ & 4.19 & 3.8 & 2.053 \\
\hline $\begin{array}{l}\text { Basal growth } \\
\text { hormone }[\mathrm{ng} / \mathrm{mL}] \\
\mathrm{N}:(0.00-10.00)\end{array}$ & 6.91 & 1.04 & 0.27 \\
\hline $\begin{array}{l}\text { Insulin-like growth } \\
\text { factor [ng/mL] } \\
\mathrm{N}:(115-307)\end{array}$ & 1046 & 404 & 206 \\
\hline $\begin{array}{l}\text { IGF binding protein } 3 \\
\text { [ng/mL] } \\
\mathrm{N}:(3500-7000)\end{array}$ & 9620 & 6600 & 5160 \\
\hline $\begin{array}{l}\text { Prolactin [mlU/L] } \\
\text { N: (44.52-375.24) }\end{array}$ & 248.676 & 326.904 & 133.348 \\
\hline $\begin{array}{l}\text { Cortisol at } 8.00 \\
\text { [nmol/L] } \\
\mathrm{N}:(118.6-618)\end{array}$ & 547.8 & 572.6 & 411.8 \\
\hline $\begin{array}{l}\text { Adrenocorticotrophic } \\
\text { hormone }[\mathrm{pg} / \mathrm{mL}] \\
\mathrm{N}:(0.00-46.0)\end{array}$ & 8.6 & 34.3 & 40.8 \\
\hline $\begin{array}{l}\text { Luteinizing hormone } \\
\text { [IU/L] } \\
\mathrm{N}:(1.21-11.48)\end{array}$ & 11.48 & 12.81 & 7.68 \\
\hline $\begin{array}{l}\text { Follicle-stimulating } \\
\text { hormone [IU/L] } \\
\mathrm{N}:(1.0-19.08)\end{array}$ & 35.5 & 40.04 & 35.17 \\
\hline $\begin{array}{l}\text { Testosterone } \\
\text { [nmol/L] } \\
\mathrm{N}:(7.96-27.3)\end{array}$ & 5.93 & 8.21 & 3.43 \\
\hline
\end{tabular}




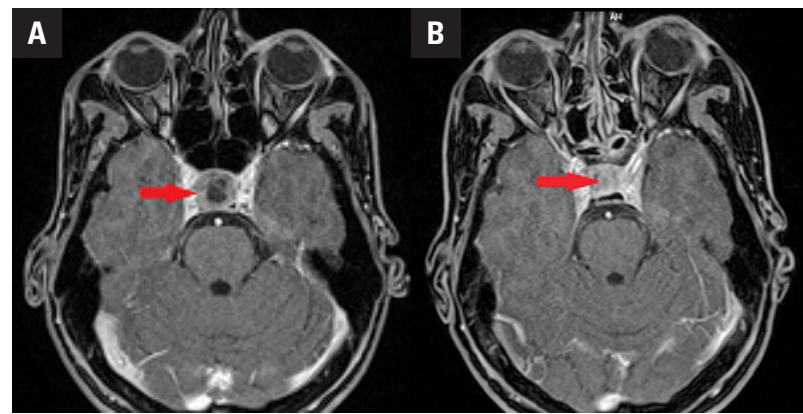

Figure 1. Head MRI a postcontrast axial images. A. Preoperative, B. After the operation

macroadenoma was performed. Histopathological and immunohistochemical findings revealed a tumour with solid growth pattern, with no significant nuclear atypia and with loss of reticulin. The tumour was producing growth hormone and weakly/controversially was producing prolactin, $\mathrm{FSH}, \mathrm{LH}$, thyroid-stimulating hormone (TSH), and adrenocorticotropic hormone (ACTH) was not secreted (Fig. 2A). The proliferative activity (Ki-67 index) was less than 1\%, E-Cadherin, CHRA, and SY-38 were positive, and P-53 was negative (Fig. 2B). The presence of infertility with clinical features, namely small, firm testes, lack of secondary male sexual characteristics (sparse body hair), as well as laboratory tests confirming hypergonadotropic hypogonadism, suggested a possibility of Klinefelter's syndrome. The patient did not report problems with sexual function. Clinically he had a penis of adequate size and no gynecomastia. Testicular ultrasound showed testicular long axis of $28 \mathrm{~mm}$ and no other pathologies. Examination of sperm confirmed azoospermia. A chromosomal karyotyping revealed a 47, XXY, confirming the diagnosis of KS. Testosterone replacement therapy, although recommended, was declined by the patient at this time. Postoperatively, elevated plasma concentration of $\mathrm{GH}$ levels persisted without adequate suppression after glucose administration as well as elevated plasma concentration of IGF-1 and IFGBP3. Treatment by somatostatin analogues (lanreotide) was initiated at $120 \mathrm{mg}$ every 28 days. Control MRI of the sella 6 months post surgery demonstrated a residue of pituitary adenoma size of $14 \times 14 \times 7 \mathrm{~mm}$ (Fig. 1B). Subsequently, an endoscopic revision of the residue was performed. After second surgery GH, IGF-1, and IGF BP3 plasma levels normalized, indicating a beneficial effect of surgical treatment. Treatment with somatostatin analogues was discontinued. At present, the patient

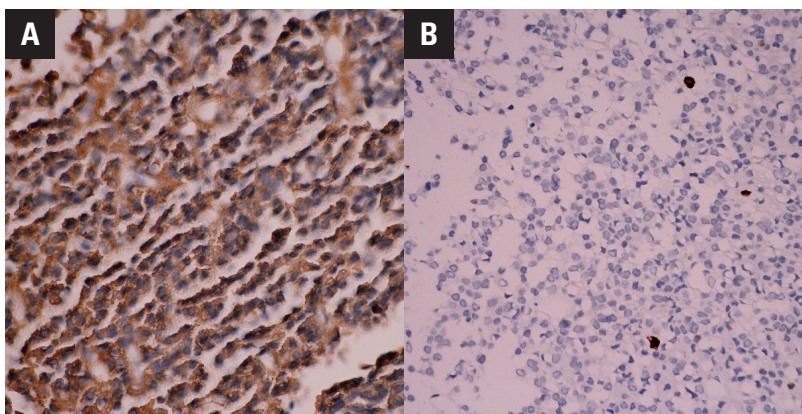

Figure 2.A. Strong staining for growth hormone (magnification $x 600) ; B$. Ki-67 proliferation index of $1 \%$ (magnification $x 400$ )

has started i.m. testosterone (testosterone decanoate) replacement therapy at $1000 \mathrm{mg}$ every 3 months.

In our case report, we describe the presence of growth hormone-producing pituitary macroadenoma in a patient with Klinefelter's syndrome that had not been previously diagnosed. Delayed diagnosis of KS is usually caused by diversity of clinical manifestations of the disease as well as lack of genital examination during routine clinical examinations. The diagnosis of acromegaly is also often delayed due to the slow progression of clinical signs over a period of many years [3]. Early diagnosis of these conditions can lead to improvement of the quality of life with reduced morbidity and mortality [4]. According to our knowledge, only 4 cases of combined acromegaly and KS were published to date. Our report highlights the importance of complete hormonal screening in patients because a single rare diagnosis (acromegaly) does not rule out other endocrinological conditions (Klinefelter syndrome).

\section{Conflict of interest}

The authors declare that they have no conflicts of interest concerning this article. All authors have read and approved the final form of this article.

\section{References}

1. Capatina C, Wass JAH. 60 YEARS OF NEUROENDOCRINOLOGY: Acromegaly. J Endocrinol. 2015; 226(2): T141-T160, doi: 10.1530/JOE-15-0109, indexed in Pubmed: 26136383.

2. Groth K, Skakkebæk A, Høst C, et al. Klinefelter Syndrome - A Clinical Update. J Clin Endocrinol Metab. 2013; 98(1): 20-30, doi: 10.1210/jc.2012-2382.

3. Esposito D, Ragnarsson O, Johannsson G, et al. Prolonged diagnostic delay in acromegaly is associated with increased morbidity and mortality. Eur J Endocrinol. 2020; 182(6): 523-531, doi: 10.1530/EJE-20-0019, indexed in Pubmed: 32213651

4. Sabir A, Zagga A, Sahabi S, et al. Klinefelter s syndrome: Report of a case from Sokoto, Northern Nigeria and review of literature. Sahel Med J. 2013; 16(1): 32-34, doi: 10.4103/1118-8561.112070, indexed in Pubmed: 112070. 